\title{
The Serological Glassification of Varieties of Lactobacillus casei
}

\author{
By JENNIFER GLASTONBURY AND K. W. KNOX \\ Institute of Dental Research, United Dental Hospital, \\ Sydney, New South Wales, Australia
}

(Received 23 July 1962)

\begin{abstract}
SUMMARY
A comparison has been made between the serological properties of $\mathbf{3 5}$ strains of Lactobacillus casei and the carbohydrate components of corresponding cell-wall preparations. All strains of L. casei var. rhamnosus belonged to serological group $\mathrm{C}$, whereas strains of $L$. casei var. casei belonged to group $\mathrm{B}$ or $\mathrm{C}$. Rhamnose was the major cell-wall component of group B strains, galactose and glucose being minor and variable components. Of the group C strains only those classified as L. casei var. rhamnosus contained significant amounts of rhamnose in the cell wall. All strains in group C, however, contained galactose and glucose as major cell-wall components.
\end{abstract}

\section{INTRODUCTION}

The studies of Sharpe (1955 $a$ ) and Sharpe \& Wheater (1957) showed that strains of Lactobacillus case $i$ belong to one of two serological groups, designated B and C and that group $\mathrm{C}$ also contained strains of L. casei var. rhamnosus. Subsequently soluble group-specific products were isolated from cell walls of the strains of $L$. case $i$ and $L$. casei var. rhamnosus used by Sharpe, and their properties described (Knox \& Brandsen, 1962; Knox, 1963). From a comparison of the chemical analyses and serological reactions of the preparations several conclusions were drawn. First, walls from strains of $L$. casei group B had a high rhamnose:glucose ratio and serological specificity was predominantly associated with rhamnose. Secondly, wall from the strain of $L$. casei group $\mathrm{C}$ had a low rhamnose:glucose ratio and serological specificity was predominantly associated with glucose. Thirdly, wall from two strains of $L$. casei var. rhamnosus had an intermediate rhamnose: glucose ratio; from both strains two products were isolated which were readily distinguishable serologically and chemically but in each glucose was responsible for serological specificity. To test whether these conclusions were generally applicable, a survey has now been made of the serological properties and cell-wall components of several strains of $L$. casei isolated from saliva (Featherstone, Murphy, Spies \& Goldsworthy, personal communication).

\section{METHODS}

Organisms. Cultures of organisms used by Sharpe (1955a) were obtained from the National Collection of Type Cultures, Colindale, London (designated NCTC), the National Institute for Research in Dairying, Reading, England (NIRD) and the National Collection of Industrial Bacteria, Torry Research Station, Aberdeen, Scotland (NCIB). These organisms were Lactobacillus casei NIRD H 831 and L. casei 
NIRD DECP belonging to serological group B, and L. casei NIRD R 094 and L. helveticus NCTC 6375 (L. casei var. rhamnosus) of group C. The other strains of $L$. casei which we have used had been classified by Mr J. L. Featherstone, Mr M. D. Murphy, Mr H. C. Spies and Dr N. E. Goldsworthy, who communicated their results to us and gave us cultures of their organisms: 24, were designated $L$. casei var. casei and 11 L. case $i$ var. rhamnosus. The studies of various workers have shown that these two varieties account for $80-85 \%$ of the strains of $L$. casei (Davis, 1955; Rogosa et al. 1953; Featherstone, Murphy, Spies \& Goldsworthy, personal communication).

Media. Cultures for inoculation into rabbits and for the preparation of $\mathrm{HCl}$ extracts were grown in the appropriate media described by Sharpe $(1955 b)$. The group sera used were those prepared for the previous investigation (Knox, 1963).

Methods. The procedures used for preparing and analysing cell-wall preparations have been described previously (Knox \& Brandsen, 1962; Knox, 1963).

Precipitin tests. Qualitative precipitin tests were performed on acid extracts of organisms (Sharpe, 1955a) and on lysates of cell wall. Lysates were prepared by incubating samples of cell walls (10-12 mg. dry wt.) for 2 days at $37^{\circ}$ with $0.5 \mathrm{ml}$. of streptomyces muralytic enzyme (McCarty, 1952 $a, b$; Knox, 1963). Certain of these lysates were also examined by the Ouchterlony method (Ouchterlony, 1953).

\section{RESULTS}

Serological classification. Thirteen strains of Lactobacillus casei var. casei belonged to group B. Eleven strains of $L$. case $i$ var. case $i$ and all (11) strains of $L$. case $i$ var. rhamnosus belonged to group $\mathrm{C}$.

Cell-wall lysates were prepared from about half the strains in each category and in each case the serological classification was confirmed by qualitative precipitin tests and the Ouchterlony technique. The Ouchterlony test revealed that extracts of group B organisms contained only one component which gave a precipitate with antiserum to Lactobacillus NIRD R 094. Serological identity was established between the product present in the extracts and purified fraction II from strain NIRD R 094 (Knox, 1963). Extract of group $\mathrm{C}$ organisms contained a single component reacting with antiserum to strain NIRD H 831; the product in the extracts was serologically identical with the purified fraction II isolated from strain NIRD H 831 .

\section{Carbohydrate components of wall preparation}

Carbohydrate chromatography. All preparations contained glucose. Also, all preparations contained galactose, except two from strains of Lactobacillus case $i$ var. casei, group B. The 6-deoxyhexose component moved with the same $R_{F}$ value as rhamnose.

Qualitative analyses. Analyses of six typical cell-wall preparations are given in Table 1. The analyses for organisms in each of the three categories are grouped in Table 2. The sum of the values for rhamnose, glucose and galactose lay between $\mathbf{3 2}$ and $42 \%$ for most strains of Lactobacillus casei var. casei. Where different figures were obtained the analytical results have been given separately. Nine strains of L. casei var. rhamnosus contained rhamnose and for eight of these the sum of the analytical values was $47-67 \%$. Two strains of $L$. casei var. rhamnosus did not contain rhamnose; these results are given separately. 
The molar ratio of rhamnose to glucose was calculated for each strain, and the results are shown in Table 3 . The molar ratios of glucose to galactose varied over a wide range for strains in serological group $\mathbf{B}$. With strains in group $\mathbf{C}$, however, the molar ratio lay between $0 \cdot 72: 1$ and $1: 1$ for 10 of the 11 strains of Lactobacillus casei var. casei, and the 2 strains of $L$. casei var. rhamnosus which did not contain rhamnose. In contrast only 3 of the 9 remaining strains of $L$. casei var. rhamnosus gave a value within this range, the ratios extending from $0 \cdot 33: 1$ to $2 \cdot 1: 1$.

Table 1. Carbohydrate components of typical cell-wall preparations from varieties of Lactobacillus casei

$\begin{array}{cccccc}\text { Variety } & \begin{array}{c}\text { Strain } \\ \text { (identifi- } \\ \text { cation no.) }\end{array} & \begin{array}{c}\text { Serological } \\ \text { group }\end{array} & \begin{array}{c}\text { Rhamnose } \\ (\%)\end{array} & \begin{array}{c}\text { Glucose } \\ (\%)\end{array} & \begin{array}{c}\text { Galactose } \\ (\%)\end{array} \\ \text { casei } & \mathbf{5} & \text { B } & 20 & 10 & 9 \\ & 21 & \text { B } & 19 & 15 & 8 \\ & 1 & \text { C } & 0 & 15 & 20 \\ \text { rhamnosus } & 16 & \text { C } & 0 \cdot 5 & 18 & 22 \\ & 15 & \text { C } & 19 & 13 & 24 \\ & 110 & \text { C } & 27 & 23 & 12\end{array}$

Table 2. Summary of cell-wall analyses from varieties of Lactobacillus casei

\begin{tabular}{|c|c|c|c|c|c|c|}
\hline Variety & $\begin{array}{c}\text { Sero- } \\
\text { logical } \\
\text { group }\end{array}$ & $\begin{array}{l}\text { Total } \\
\text { no. of } \\
\text { strains }\end{array}$ & $\begin{array}{c}\text { Rhamnose } \\
(\%)\end{array}$ & $\begin{array}{c}\text { Glucose } \\
(\%)\end{array}$ & $\begin{array}{c}\text { Galactose } \\
(\%)\end{array}$ & $\begin{array}{c}\text { Total } \\
(\%)\end{array}$ \\
\hline casei & B & $\begin{array}{r}11 \\
2\end{array}$ & $\begin{array}{l}18-28 \\
12,41\end{array}$ & $\begin{array}{l}4-13 \\
4,4\end{array}$ & $\begin{array}{l}0-9 \\
3,8\end{array}$ & $\begin{array}{l}32-42 \\
19,53\end{array}$ \\
\hline \multirow[t]{2}{*}{ casei } & C & 8 & $\begin{array}{c}0-2 \cdot 8 \\
(6 \cdot 7)^{*}\end{array}$ & $14-18$ & 15-23 & $31-45$ \\
\hline & & 3 & $0-1 \cdot 0$ & 6-10 & $11-16$ & $21-23$ \\
\hline \multirow[t]{2}{*}{ rhamnosus } & C & 8 & 16-29 & $\begin{array}{c}12-23 \\
(7)^{*}\end{array}$ & $12-33$ & $47-67$ \\
\hline & & $\begin{array}{l}1 \\
2\end{array}$ & $\begin{array}{l}26 \\
0.5,0.5\end{array}$ & $\begin{array}{c}7 \cdot 5 \\
16,26\end{array}$ & $\begin{array}{l}7 \\
22\end{array}$ & $\begin{array}{l}41 \\
39,56\end{array}$ \\
\hline
\end{tabular}

* For all except one strain the values lay within the range indicated. The remaining figure is given in brackets.

Table 3. Molar ratios of rhamnose to glucose for the cell-rwall preparations from varieties of Lactobacillus casei

$\begin{array}{cccc} & \begin{array}{c}\text { serological } \\ \text { group B }\end{array} & \overbrace{\text { var. }}^{\text {serological group C }} \\ \text { Molar ratio } & \text { var. casei } & \text { casei } & \begin{array}{c}\text { var. } \\ \text { rhamnosus }\end{array} \\ <0 \cdot 10 & 0 & 6 & 2 \\ 0 \cdot 10-0 \cdot 31 & 0 & 5 & 0 \\ 1 \cdot 1-1 \cdot 7 & 4 & 0 & 7 \\ \mathbf{2} \cdot 2-3 \cdot 0 & 4 & 0 & 0 \\ 3 \cdot 1-4 \cdot 5 & 3 & 0 & 2 \\ 5 \cdot 5-7 \cdot 5 & 1 & 0 & 0 \\ 9 \cdot 1-19 \cdot 8 & 1 & 0 & 0\end{array}$




\section{DISCUSSION}

In an extensive survey of more than 400 Lactobacillus strains Sharpe (1955a) classified $70 \%$ of these strains into six serological groups. There was close agreement between these groupings and the physiological groups defined by Briggs (1953). In a subsequent discussion of the classification of Lactobacillus Rogosa \& Sharpe (1959) indicated that most strains of Lactobacillus casei var. casei and L. casei var. alactosus belong to serological group $\mathbf{B}$, the remainder belonging to group $\mathrm{C}$; all strains of L. casei var. rhamnosus, however, belonged to group C.

The strains examined in the present work had been classified on the basis of physiological tests. All strains of Lactobacillus casei var. rhamnosus have been found to belong to serological group $\mathrm{C}$ whereas strains of $L$. case $i$ var. case $i$ belong to either group B or group C. The conclusion of Sharpe that there is a close agreement between serological and physiological groupings of Lactobacillus has therefore been confirmed.

The serological groupings depend on cell-wall components and previous studies have shown that the group-specific products isolated from the cell wall of strains of Lactobacillus case $i$ var. case $i$ and $L$. case $i$ var. rhamnosus are predominantly polysaccharide. The quantitative analyses performed on cell-wall preparations from 35 additional strains of groups $\mathbf{B}$ and $\mathbf{C}$ indicate that polysaccharides are important components of the cell-wall preparations, the analyses totalling 31-45\% for 19 of the 24 strains of $L$. casei var. casei. In agreement with earlier results (Knox, 1963) the carbohydrate content of wall preparations from strains of $L$. casei var. rhamnosus were even higher $-47-67 \%$ for 8 of the 9 rhamnose-containing strains. Two strains of $L$. casei var. rhamnosus did not contain rhamnose as a cell-wall component; the analyses and serological properties are therefore those expected of a strain of L. casei var. casei of serological group C.

Table 3 illustrates the close relationship between serological groupings of the different organisms and the molar ratio of rhamnose to glucose. As observed previously, organisms belonging to serological group B are characterized by a high rhamnose:glucose ratio which is greater than $2: 1$ for a majority of the strains $(9$ of 13). Organisms in serological group $\mathrm{C}$ on the other hand are characterized by a lower rhamnose:glucose ratio-less than $2: 1$ for all but 2 of the 22 strains. Furthermore, rhamnose was only present as a major component in the wall preparations of strains of Lactobacillus casei var. rhamnosus; for all strains of $L$. casei var. casei the rhamnose content was very low.

Galactose and glucose are present as variable but minor components of preparations from group $\mathbf{B}$ organisms, an observation in agreement with the conclusion (Knox, 1963) that rhamnose is responsible for the serological specificity. Strains of group $\mathrm{C}$ organisms, however, contain greater amounts of galactose and glucose and, furthermore, for those strains which do not contain rhamnose, the molar ratios of glucose to galactose lie within the narrow range of $0.72: 1$ to $1: 1$. The variable glucose:galactose ratios for strains of Lactobacillus casei var. rhamnosus may be accounted for by variations in the relative amounts of the two specific polysaccharides previously shown to be present (Knox, 1963).

These results conform with those expected from the earlier studies on groupspecific components, and certain generalizations now appear to be valid. First, all 
strains of Lactobacillus casei var. casei of serological group B contain rhamnose as a major cell-wall component. Secondly, strains of $L$. casei var. casei of serological group $\mathrm{C}$ do not contain rhamnose, the major cell-wall carbohydrate components being galactose and glucose in about equimolar proportions. Thirdly, rhamnose is a major component of the cell wall of most strains of $L$. case $i$ var. rhamnosus: these strains also belong to serological group $\mathrm{C}$, for, as shown previously, rhamnose does not contribute to their serological specificity.

This work was supported by a grant from the National Health and Medical Research Council of Australia.

\section{REFERENCES}

Briggs, M. (1953). The classification of lactobacilli by means of physiological tests. J.gen. Microbiol. 9, 234.

Davis, G. H. G. (1955). The classification of lactobacilli from the human mouth. J. gen. Microbiol. 13, 481.

KNox, K. W. (1963). Isolation of group specific products from Lactobacillus casei and L. casei var. rhamnosus. J. gen. Microbiol. 31, 59.

KNox, K. W. \& BrandSEN, J. (1962). The isolation of components from the cell wall of Lactobacillus casei. Biochem. J. 85, 15.

McCARTY, M. (1952a). The lysis of Group A hemolytic streptococci by extracellular enzymes of Streptomyces albus. I. Production and fractionation of the lytic enzymes. J. exp. Med. 96, 555.

McCarty, M. (1952b). The lysis of Group A hemolytic streptococci by extracellular enzymes of Streptomyces albus. II. Nature of the cellular substrate attacked by the lytic enzymes. J. exp. Med. 96, 569.

OUChTERLONY, Ö. (1953). Antigen-antibody reactions in gels. IV. Types of reaction in coordinated systems of diffusion. Acta path. microbiol. scand. 32, 231.

Rogosa, M. \& Sharpe, M. E. (1959). An approach to the classification of the lactobacilli. J. appl. Bact. 22, 329.

Rogosa, M., Wiseman, R. F., Mitchely, J. A., Disraely, M. N. \& Beaman, A. J. (1953). Species differentiation of oral lactobacilli from man including descriptions of Lactobacillus salivarius nov.spec. and Lactobacillus cellobiosus nov.spec. J. Bact. 65, 681 .

ShARPE, M. E. $(1955 a)$. Serological classification of lactobacilli. J. gen. Microbiol. 12, 107 .

Sharpe, M. E. $(1955 b)$. Haptene substances in culture media for lactobacilli. J. gen. Microbiol. 13, 198.

Sharpe, M. E. \& Wheater, D. M. (1957). Lactobacillus helveticus. J. gen. Microbiol. 16, 676. 